\title{
HØJE KVINDER OG FEDE MAND: KARIKATUR SOM ET STILISTISK VIRKEMIDDEL I KAREN BLIXENS FORTALLINGER
}

\author{
RADKA STAHR
}

\begin{abstract}
Tall Women and Fat Men: Caricature as a Stylistic Device in Karen Blixen's Short Stories

Visual art is one of the fundamental inspirational influences in the work of Karen Blixen and it is reflected not only on the thematic level, but also in the technical construction of the text. One of its manifestations is the use of the caricature technique. Not only does Blixen thematize the substance of caricature on the textual level, she also uses it to describe the characters, over-emphasizing one of the character's particular physiognomic features. The over-emphasized part often gains a symbolic meaning in relation to the character or even to the theme of the story. In addition, certain characteristic features can be found in more characters appearing in different stories; when comparing the meaning of the given feature across stories, we can reveal archetypal features of Blixen's heroes and heroines, who are often depicted by means of caricature.
\end{abstract}

Keywords: Karen Blixen; Danish literature; caricature; literary caricature; archetype

\section{Indledning}

Et aflangt, tyndt ansigt med indsunkne kinder og mange rynker, langstrakt hage, stikkende blik og en turban eller en hat trukket dybt ned i panden, spinkel figur og foroverbøjet stilling: sådan bliver Karen Blixen i reglen gengivet på forskellige nutidige malerier og tegninger. ${ }^{1}$ Sådan en gengivelse af Blixen kendetegnes ved en karikerende tendens, fordi den ikke stræber efter at fremstille personens virkelighedsnære billede, men vælger et typisk karakteristisk træk (eller flere) ved personens udseende og overdriver det på en sådan måde, at alle betragtere klart genkender den afbildede person. Den danske

1 Jf. fx Blixens portrætter af Anne-Marie Steen Petersen, der kan betragtes som Blixens „hofportrætør“. Hun påvirkede vores nuværende visuelle opfattelse af den danske baronesse i en vis grad, fordi hendes tegninger plejer at udkomme som illustrationer til artikler om Blixen i Politiken, de bliver udstillet på udstillinger og Petersen er også illustrator af Thorkild Borup Jensens bogserie om de danske kanonforfattere med karikerende tegninger af forfatterne på omslaget. 
baronesse ville måske ikke være særlig glad for, at hendes genkendelsestegn bygger på hendes udseende i alderdommen, men man kan antage, at hun ikke ville være imod at blive fremstillet på en forvrænget måde, fordi hun selv havde et varmt forhold til karikatur. Karen Blixen blev nemlig ikke kun genstand for karikatur, men hun har også tegnet flere karikaturer selv. I denne artikel vil jeg kort præsentere Blixen som en tegnende karikaturist og samtidig analysere, om hun også kan blive opfattet som en skrivende karikaturist, fordi de praktiske erfaringer inden for karikatur kunne finde anvendelse i hendes litterære produktion. ${ }^{2}$

\section{Blixen som en tegnende karikaturist}

Karen Blixen blev verdensberømt som forfatter, men det var billedkunsten, hun foretrak som den kunstneriske udtryksmåde i sin ungdom. Hun besøgte malerskoler i Danmark, Frankrig og Italien og studerede endda fem semestre på Det Kongelige Danske Kunstakademi i København (Blixen 1969, 19). For det meste er det de farverige billeder fra Afrika, som Blixen typisk bliver forbundet med som maler, men hun efterlod også flere tegninger og skitser, som hun har skabt hele sit liv og som vidner om hendes kunstneriske tendens til at karikere.

Kronologisk set kan vi begynde med de første maleriske forsøg fra hendes tidlige ungdom. Den kunstbegejstrede pige plejede at lave tegninger med motiver fra sin udstrakte læsning, og allerede som 15 årig tegnede hun sine egne illustrationer til Shakespeares Midtsommernattsdrøm (Lasson 12). ${ }^{3}$ Tegningerne er et tydeligt tegn på Blixens hang til karikatur på den måde, at en bestemt del af figurens fysiognomi tit bliver abnormalt fremhævet - fx den første tegning af den spinkle Titania med kæmpestore sommerfuglvinger, som optager størstedelen af billedet, eller afbildningen af Vindsel som en særlig tyk, næsten fed mand, som danner en modsætning til den skrøbelige Titania. Det næste trin repræsenterer Blixens tegninger fra hendes studium på Kunstakademiet, som er mere udarbejdede og demonstrerer hendes maleriske talent. I det andet studieår blev studerende undervist i portrætkunsten, og der bevaredes flere portrætter skabt af Blixen. Fire af dem lod hun selv trykke sammen med sit essay „Til fire kultegninger“ i Berlingske Aftenavis i 1950, hvor hun afslører sit varme forhold til billedkunsten, kommenterer forløbet af sit kunststudium samt konteksten for tilblivelsen af de fire trykte tegninger. På disse tegninger bliver den karikerende teknik næsten ikke brugt (det drejer sig jo om kunstneriske portrætter af ukendte mennesker, og studerende skulle lære en virkelighedsnær gengivelse af figuren), men det er spændende at betragte tegningernes titler. De fleste titler er ukonkrete i forhold til modellen, men samtidig bliver de specificeret

2 Betydningen af den visuelle kunst i Blixens forfatterskab bliver analyseret i flere studier, som først og fremmest fokuserer på afspejlingen af billedets tematiske side, dvs. de analyserer refleksionen af figurer eller motiver fra billedkunsten i tekster (fx Charlotte Engberg, som udforsker kunstens inspirationspotentiale eller Ivan Ž. Sørensen, som stræber efter at finde konkrete artefakter i konkrete tekstpassager). Der findes dog ikke så mange analyser, som fokuserer på selve maleriske teknikker, Blixen kunne benytte sig af til at opbygge de mentale billeder i sine fortællinger. Karikaturen kan forstås som sådan en malerisk teknik.

3 Tegningerne blev først offentliggjort efter Blixens død i samlingen Karen Blixens Tegninger editeret af Frans Lasson, Blixens ven og en god kender af hendes maleriske kunst. 
gennem et særpræg, uanset om de går tilbage til udseende eller tøj, som fx Gammel mand med skaeg, Ung pige med højhalset bluse, Ung mand med sydvest, Kvinde med glorie, Yngre mand med overskog (Asmussen og Stenkjær 47-56). Sådan en betegnelse er ikke noget usædvanlig i portrætkunsten, fordi mange billeder bliver benævnt tilbagevirkende. Men vi kan alligevel ane malerens tendens til at fokusere på et konkret træk ved figurens udseende og bruge det som identifikation for hele afbildningen.

Det sidste eksempel på Blixens forkærlighed for karikatur er ubestrideligt, fordi det gælder vittighedstegninger, som hun selv tegnede i 1907 og offentliggjorde (under pseudonymet Peter Lawless) i det politisk-satiriske ugeblad Klods-Hans (Henriksen 65). En af dem viser to fornemme damer, som mødes og hilser på hinanden på en affekteret måde. Tegningen er ledsaget af en tekst, som gør grin med kvindernes daværende stilling og manglende meningsfulde fritidsaktiviteter på satirisk vis. ${ }^{4}$ Det er damernes kropsstilling, som bliver karikeret, fordi Blixen viser dem i en meget krukket positur, hvor de holder fingerspidserne i hilsen med en affekteret kropsholdning og den nødvendige afstand, som det bliver foreskrevet af samfundsnormen. Det er ikke nogen konkrete damer, som kan genkendes i karikaturen, men det er et generaliserende vrængbillede af hele den aristokratiske klasse, hvor kvindernes livsopgave er at pynte husholdet. Blixens karikatur uddyber vittighedens kerne og beriger den med en satirisk note.

\section{Blixen som en skrivende karikaturist}

Karikaturen behøver ikke kun at blive begrænset til billedkunsten, men kan også bruges i litterære tekster. Det gælder om anvendelsen af en særlig skrivestil, som - ligesom den klassiske, tegnede karikatur - gengiver en person og overdriver et karakteristisk træk i dennes udseende, gestus, egenskaber eller samfundsstilling. Typisk angår den litterære karikatur en berømt person, som læseren kan genkende, og den bliver fremstillet på en satirisk måde. En litterær karikatur stræber altså efter at opnå det samme mål som en tegnet karikatur, bare med sine egne sproglige midler (Gernhardt 217).

Der findes spor af karikatur på to niveauer i Blixens fortællinger: For det første er det dens tematiske refleksion på tekstens overflade, når karikaturen direkte bliver omtalt og tematiseret i dens væsen. Der findes flere eksempler på disse eksplicitte referencer hos Blixen, fx hedder det i fortællingen „En opbyggelig Historie“:

Hvert eneste Kunstværk er paa samme Tid sin egen Idealisation, og sin egen Karikatur, et Vrængbillede af sig selv! Og det er Publikum, der hvert Øjeblik, afgør, hvilket af de to, det skal være. Naar Publikums Hjerte bevæges og rystes af Værket, saa at de med Taarer af Stolthed og Sønderknuselse udraaber det som et Mesterværk, da bliver det, hvad det jo altid har været, et Mesterværk. Naar de fornægter det som flovt og værdiløst, da kommer Karikaturen deraf grinende frem, da er det i samme Øjeblik, hvad det altid har været, flovt og værdiløst. (Blixen 1978, 242)

4 Vittigheden under tegninger lyder således: „-Hvor er De dog optaget, Fru Oberstinde! - Ak ja, siden jeg er bleven Formand for ,Foreningen for kvindelig Husflid“er jeg saamænd ikke hjemme en eneste Dag!" (Henriksen 65). 
Karikaturen bliver opfattet næsten som en modsætning til idealisation og bliver forbundet med negative konotationer som flovt og værdiløst. Men samtidig befinder modsætningerne sig i harmoni, fordi et kunstværk kan fortolkes som begge på samme tid; det afhænger kun af betragteren, hvilken fortolkning han vælger. Blixen anser ikke karikaturen som en satirisk kunstform her, men fokuserer snarere på karikaturens væsen: at skabe et usmigrende vrængbillede af den oprindelige tilstand. På samme måde forekommer en tematisk reference til karikatur i fortællingen "Et Familieselskab i Helsingør", hvor forandringen af Fannys udseende efter flere år bliver skildret blandt andet således: „Hendes fordums fugleagtige Lethed var karikeret i pludselige og umotiverede smaa Sæt og Ryk" (Blixen 1988, 291). Figurens nuværende udseende bliver gengivet som tab af den oprindelige skønhed - karikaturen bliver negativt konnoteret igen. Ligesom i det forrige tilfælde er det publikum, som afgør, om det nye udseende er en karikatur eller et mesterværk; Fanny holder nemlig en fest med gamle venner, som har kendt hende i mange år og har oplevet forandringen sammen med hende, og derfor ikke bemærker, at hun ser værre ud. Kun en ny betragter, som ikke har set hende i alle de år, kan blive negativt overrasket. Karikaturens motiv knytter sig til temaet i fortællingen, fordi den centrale konflikt opstår som konfrontationen mellem figurernes smukke og ideelle liv i Helsingør på deres ungdomstid og den aktuelle triste situation. Det er ikke kun Fannys skønhed, men hele familiens liv, der bliver til en bedrøvet karikatur.

Ud over det tematiske niveau spiller karikaturen også en anden, endnu vigtigere rolle i Blixens fortællinger: den bliver brugt som en stilistisk metode til beskrivelse af personer. Nogle figurer bliver karakteriseret gennem ét dominerende træk i udseende, som bliver overdrevet på bekostning af oplysningerne om andre kropsdele. ${ }^{5}$ Et konkret karakteristisk træk optræder endda tit ved beskrivelse af figurer i forskellige fortællinger, og ved sammenligning af alle figurer i Blixens persongalleri viste det sig, at der findes to grundtyper, næsten arketyper i hendes tekster: høje kvinder og tykke mænd.

\subsection{Høje kvinder}

Et af de mest slående fysiognomiske tegn, som Blixen opbygger sine karakterbeskrivelser omkring, er abnormal højde. Det er først og fremmest de kvindelige karakterer, som bliver bestemt af denne egenskab - $\mathrm{fx}$ den høje og frodige pige Jensine i fortællingen „En Historie om en Perle“, Rosa, en overraskende stor pige for sin alder, i fortællingen „Petr og Rosa“ eller Malli i fortællingen „Storme“. Dette karakteristiske tegn vises tydeligt ved figuren af Athene i fortællingen "Aben“, som bliver beskrevet som „en kraftig, ung Kvinde paa 18 Aar, seks Fod høj og tilsvarende bred, med et Par Skuldre, der kunde løfte og bære en Tønde Hvede. Ved de fyrre vilde hun nok blive kolossal, men endnu var hun for ung til Fedme og saa rank som et Lærketræ“ (Blixen 1988, 132). Det eneste, vi får at vide om pigens udseende, er, at hun har rødt hår, en ædel pande, fregner, lys hud, en mørkere cirkel omkring iris og et rundt ansigt. Ingen af disse egenskaber får dog mere plads end

5 Et særligt træk ved den fysiognomiske beskrivelse af Blixens figurer reflekterer bl.a. Charlotte Engberg, som forbinder fremhævelsen af én kropsdel med den generelle indflydelse af portrætter på Blixen. Hun betegner opbygning af beskrivelsen som „en særlig fetichistisk fokusering i personbeskrivelsen“ (Engberg 17). Derudover peger Engberg på typologisering og depersonalisering af Blixens figurer, som mangler psykologisk dybde (Engberg 93). 
blot en kort nævnelse. Højden bliver omtalt flere steder i teksten og bliver så til Athenes genkendelsestegn. Hendes højde og fysiske styrke svarer samtidig til hendes natur, fordi hun er en meget stærk og frigjort kvinde, en republikaner, som nægter at gifte sig. Herfra kan vi trække det første karakteristiske træk ved de høje og kraftige kvinder i Blixens fortællinger ud: deres ydre fysiognomi er en afspejling af en stor og selvsikker sjæl, der går ud over daværende fremstilling af en kvinde. Det samme gælder for andre høje kvinder hos Blixen - fx for Jensine, der vil ikke underordne sig i ægteskabet, for Malli, der viser sin indre styrke i løbet af den ødelæggende storm og for Rosa, som - selvom hun er meget ung - allerede er kommet godt i gang med at manipulere mændene omkring sig.

De høje og selvsikre kvinder fremkalder således visse maskuline konnotationer i Blixens tekster. Forbindelsen mellem det feminine og det maskuline princip hos en kvinde bliver direkte tematiseret i fortællingen „Karyatiderne“:

Childerique var paa denne Tid beruset af sin Frihed, men paa ingen Maade af sin Magt. Hun havde som Barn sørget over, at hun ikke var en Dreng. [...] Hun var ogsaa, da hun var sytten Aar, trykket af, at hun var saa høj af sin Alder. Det var da, som om hun resolut traf sit Valg overfor begge de to Problemer i sin Tilværelse: da det nu engang ikke kunde være anderledes, saa maatte Verden hellere straks faa Ulykken at se i hele dens Udstrækning. Hun holdt sig meget rank, som for at vise sig i sin fulde Højde, og hun hengav sig med al sin Kraft til sin Skæbne som Pige, - ligesom paa Trods fulgte hun alle sin Naturs mest kvindelige Luner, og undgik ganske aabenhjertigt alle mandlige Væsener, undtagen sin lille Broder. (Blixen 1957, 110-111)

Den unge pige bliver bekymret over sin mærkbare højde, ligesom over det, at hun ikke er en dreng. Men hun er internt så stærk, at hun kan klare begge problemer og vende dem til sin fordel. Sammenlignet med Athene er Childerique en gift kvinde nu, men hendes ægteskab er kun på overfladen uproblematisk. I løbet af handlingen kan læseren konkludere af dialoger og fortællerens kommentarer, at pigen er ulykkeligt forelsket i sin bror. Gåpåmod og lidenskab, de forudbestemte egenskaber hos en høj kvinde fra Blixens persongalleri, kommer til udtryk, når Childerique hører om sin brors forlovelse og forsøger at forhindre den. Betydningen af den kvindelige styrke afspejles i selve titlen på fortællingen, som henviser til de høje, kraftige og smukke kvindefigurer, som er i stand til at bære huse på deres hoveder.

Parallellen mellem det ydre udseende og den indre styrke når sit højdepunkt i karakteren af Lady Flora Gordon i fortællingen „Kardinalens tredie Historie“. På grund af sin højde gør den skotske dame indtryk på enhver, som hun møder: „Thi hun var en Kæmpekvinde, større end nogen af dem jeg som Barn har set fremvist paa Markeder. Hvor hun kom, ragede hun et Hoved op over de Mænd, med hvem hun underholdt sig. Hun var tilsvarende skulderbred og hoftestærk“ (Blixen 1957, 70-71). En klar parallel til Athene dukker op i figurens beskrivelse, fordi Lady Flora også har rødt hår, lidt fregnet hud og er en meget utilgængelig kvinde med et negativt forhold ikke kun til mænd, men faktisk til alle mennesker. Hovedpersonens abnormale højde er et væsentligt træk, der understreges ved en intertekstuel reference til Jonathan Swifts berømte værk Gullivers rejser. Den eksplicitte reference til de berømte historier om lilleputter og kæmper afspejler Lady Floras tilgang til sine omgivelser: hun opfører sig som en kæmpe i lilliputternes land og ser ned på sine medmennesker på en spottende måde. Hun benytter sig faktisk også af en 
karikerende tilgang, fordi hun reducerer andre mennesker til kun ét karakteristisk træk, deres mindre højde.

Der findes flere høje kvinder i Blixens fortællinger, som gifter sig med mindre mænd. Sådan et ubalanceret ægteskab indgår for eksempel Lady Floras forældre: „Denne Moder havde været lige saa høj og havde vejet lige saa meget som sin Datter. Lady Floras Fader derimod [...] havde været under Middelhøjde og spædt bygget“ (Blixen 1957, 72). Ægteskabet bliver ikke lykkeligt, fordi Floras mor er frygteligt jaloux på sin smukke mand. Faktisk alle ubalancerede ægteskaber i Blixens fortællinger er forudbestemte til at blive ulykkelige, fordi man forventer af en kvinde i den tid, at hun underkaster sig sin mand i ægteskabet - men det er præcis det, som de høje kvindelige figurer hos Blixen ikke er i stand til at gøre. Vi kan finde et lignende eksempel i fortællingen „Den unge Mand med Nelliken“. Læseren får at vide, at Charles er en spinkel og tynd mand og hans kone Laura er en høj kvinde: man kan derfor forvente, at deres ægteskab bliver ledsaget af komplikationer. Det er dog Charles, som er hovedpersonen i fortællingen, og Laura bliver kun til en sekundær figur fremstillet som en kærlig og hengiven kone. Ligesom i tilfældet med Lady Floras forældre er hun også forelsket i sin mand i den grad, at hun nedtoner sig selv til fordel for sin mand. Men han overvejer hele tiden at forlade hende, hvilket han i sidste ende ikke gør. Selvom Laura kun er en bifigur i fortællingen, som ikke bliver særlig beskrevet eller psykologisk uddybet, lader Blixen hende vinde på en eller anden måde og udvikle sit potentiale. Det fremgår af fortællingen „En opbyggelig Historie“, som kan betragtes som en fortsættelse eller snarere en epilog til „Den unge Mand med Nelliken“. Charles historie skaber kun en rammefortælling til et filosofisk essay, men vi får at vide, at Laura har forladt sin mand til sidst. En høj kvinde har fulgt sin forudbestemmelse og er blevet til en selvsikker og frigjort person, der godt kan leve uden en mand.

\subsection{Fede mænd}

Udover højden karakteriserer Blixen også sine figurer gennem deres vægt somme tider. Det er ikke et fundamentalt karikerende træk hos de kvindelige karakterer, fordi de plejer at være naturligt slanke, hvis ikke de er lidt kraftige i sammenhæng med deres højde. Tykkelsen bliver først og fremmest påpeget i forhold til de mandlige figurer, og den kan derfor betragtes som deres karikerende stilistiske virkemiddel. Den arketypiske betydning af de tykke mænd bliver dog ikke så udarbejdet, som det var tilfældet hos de høje kvinder, men vi kan alligevel finde to grundlæggende sammenhænge, som gælder for alle fede mænd i Blixens persongalleri. For det første er det typisk rige og mægtige mænd, som er tykke. For eksempel prins Potenziani i fortællingen „Vejene omkring Pisa“, som ikke bare er den rigeste og mest magtfulde figur blandt Blixens karakterer, men samtidig også den tykkeste. Der skabes en parallel mellem figurernes ydre og indre karakter igen: ligesom kvindernes højde forudsiger deres stærke personlighed og tilbøjelighed til emancipation, vidner mændenes fedme om deres rigdom, magt (også over kvinder) og overbevisning om deres egen vigtighed.

Fedme virker samtidig som et negativt æstetisk træk i Blixens tekster. De fleste fortællinger udspilles i det 19. århundrede, og det var en slank figur både hos mænd og kvinder, som svarede til aristokratiets ideal, mens fedme og robusthed hovedsageligt var forbundet med middelklassen (Schnurbein 138). Blixen synes at arbejde med den daværende 
tilgang; de tykke mænd plejer at være aristokrater, og deres tykkelse stridende mod tidens smag bliver negativt vurderet. Et eksempel findes allerede i indledningen til fortællingen „Vejene omkring Pisa“, hvor greven Augustus bliver skildret som „en tungsindigt anlagt ung dansk Adelsmand, som vilde have set overmaade godt ud, hvis han ikke havde haft nogen Tilbøjelighed til Fedme" (Blixen 1988, 9). Fedme danner det eneste visuelle karaktertræk ved Augustus, som læseren bliver oplyst om, således at figuren bliver karikeret gennem det. Det angår også den anden mandlige figur i fortællingen, prins Potenziani: „Tiltrods for sin enorme Fedme og det stramme Korset, hvori han var snøret ind, bevægede han sig med ubeskrivelig Ynde, som om han havde en egen Rytme i Kroppen“ (Blixen 1988, 35). Det er kun den æstetiske side af tykkelsen, som bliver implicit kritiseret, og ikke dens praktiske ulemper. Sammenfattende kan vi konstatere, at fedme ikke indikerer karakterens egenskaber eller tanker, ligesom det var tilfældet med de høje kvinder, men snarere forudsiger hans rigdom og magt samt illustrerer samfundets æstetiske værdier.

\subsection{Fremhævelse af en kropsdel og asymmetri}

Udover de fysiske dimensioner fokuserer fortælleren også tit på en bestemt del af figurens krop, især fra ansigtsområdet. Som et eksempel kan vi nævne beskrivelsen af Mizzi i fortællingen „De standhaftige Slaveejere“. Blixen har selv afsløret, at hun lod sig inspirere af Gustave Courbets maleri Tre unge engloenderinder ved et vindue, da hun skrev fortællingen (Blixen 1969, 26). Det er først og fremmest figurernes komposition og konstellation, som inspirerede forfatteren til hendes fortælling, men det er også delvis pigernes udseende, som afspejles i teksten. Størstedelen af skildringen er dog Blixens intention, fordi figurerne sidder næsten bortvendt fra beskueren på maleriet, og man kan derfor ikke se meget af deres ansigter. Beskrivelsen af Mizzi i fortællingen virker helt neutral i begyndelsen. Læseren får at vide, at hun har et lyst ansigt uden makeup og ingen rynker, mørkeblå øjne med sorte øjenvipper og høje kindben. Men som en karikaturist finder fortælleren et træk i udseendet, som han fremhæver: i dette tilfælde er det pigens mund (som man i øvrigt ikke kan se på maleriet):

Men hvad der først og sidst tiltrak sig Opmærksomheden i hendes unge Ansigt var Munden, - en tyk, overmodig, barnlig, flammende Mund, saa rød som en Rose. Ja, man kunde tro, at hele den ranke, stolte Skikkelse var skabt for paa værdig Maade at bære denne blussende Mund om i Verden. (Blixen 1978, 57)

Munden bliver således til den dominerende del ikke kun af pigens ansigt, men også af hele hendes krop. Fremhævelsen af munden kan tolkes symbolsk i forhold til Mizzis karakter og stilling. Allerede fra antikken står munden som et symbol på sandhed og løgn, fordi disse bliver udtalt gennem den - blandt andet kan man tænke på det berømte bocca della verità i Rom (Butzer 280). Fortællingen „De standhaftige Slaveejere“ har løgn, hykleri og skjult identitet som hovedtema, fordi Mizzi og hendes søster foregiver at være nogle andre, end de er, for at skjule deres kommende fattigdom. Desuden kan munden symbolisere den sensuelle kvindelighed og den kvindelige seksualitet (Butzer 281), og det kan også betragtes som et karaktertræk ved Mizzis figur. Hun bliver fremstillet som den skønneste og mest attraktive pige i selskabet på badehotellet og stiliserer sig bevidst 
i rollen som en ung, uskyldig pige, så at alle mænd bliver forelsket $i$ hende og frier til hende. Den karikerende teknik bliver brugt i overensstemmelse med kropsdelens symbolske betydning, og virker således som et stilistisk virkemiddel til at fremhæve figurens (dog foregivne) egenskaber.

Et lignende eksempel på brug af den karikerende teknik findes i fortællingen „Et Familieselskab i Helsingør". Den unge mand Morten bliver beskrevet således:

Hans Næse og Mund var skaaret ud med en grovere Haand. Men han havde den mest uforlignelige klare og rene Pande. Naar Folk talte med ham, løftede de uden at vide det Øjnene op til denne brede, ædle Pande, som om den havde straalet under en Kejsers Krone eller en Helgenglorie. (Blixen 1988, 273)

Beskrivelsens opbygning mindes om skildringen af Mizzi: først er der en relativt neutral beskrivelse, og den bestemte del af ansigtet, der danner figurens dominerende træk, kommer først til slut. En bred og ædel pande var typisk for portrætter fra renæssancen, hvor den symboliserede klogskab og aristokratisk oprindelse af den afbildede person (Sturgis og Clayson 144). Mortens pande er velegnet til den kejserlige krone og tildeler ham en heroisk aura. Panden antyder drengens forudbestemmelse til heltemod og eventyr: han bliver sømand, deltager i skibskampe, bliver pirat og bliver hængt i det eksotiske Havana til sidst. Han vender tilbage som et spøgelse, som hans søstre møder efter tredive år. Mortens nuværende udseende bliver igen beskrevet af fortælleren, og det er stadigvæk panden, som danner det dominerende træk, selvom den har forandret sig: „Den var ikke mere den lysende Tiara, som over de mørke Bryn engang havde fanget alles Øjne. Den var nu alvorlig og oprigtig uden Forbehold som et Kranium. Denne Straaleglans tilhørte ikke en Mand som beherskede Verden, men en, der ejede Graven og Evigheden“ (Blixen 1988, 309). Pandens symbolske betydning forandrer sig sammen med figurens udvikling: i stedet for den oprindelige heroiske konnotation fremkalder panden det skræmmende liv efter døden, hvor Morten lige kommer fra.

Som en sidste form for karikerende teknik hos Blixen vil jeg omtale fremhævelsen af asymmetri mellem forskellige dele af figurens krop. For eksempel bliver Laura i fortællingen „Den unge Mand med Nelliken“ beskrevet på denne måde:

Hendes Ansigt vilde have været klassisk skønt, hvis den øverste Del af det ikke havde været lidt for kort og smalt i Forhold til Underansigtet. Det samme Træk gik igen i hele hendes Legeme, Overkroppen var lidt for lille og spinkel i Forhold til Hofter og Ben. (Blixen 1978, 19)

Asymmetrien i forhold til de enkelte kropsdele udgør et negativt træk i figurens udseende, ligesom det var tilfældet med de tykke mænd. Karikaturen får ikke en symbolsk eller arketypisk betydning her, men fungerer som et æstetisk kriterium ved figurens skildring. Det behøver ikke kun at være en negativ bedømmelse, vi finder et eksempel på en positiv reflektion over asymmetrien i fortællingen „Ib og Adelaide“, hvor protagonistens „korte, runde Hage dannede en mærkeligt fængslende pikant Modsætning til hendes klassiske Overansigt med dets marmorglatte Pande" (Blixen 1957, 227). Selvom den korte hage udgør en ulige modsætning til den klassiske, dvs. høje pande, vurderes asymmetrien positivt af fortælleren, fordi den tilføjer en særlig skønhed til figuren. 


\section{Afslutning}

En karikatur bliver mest forstået som en malerisk kunstform, men dens fremgangsmåde kan også bruges som et stilistisk virkemiddel i litterære tekster. Som det viste sig $i$ analysen af Blixens fortællinger, tematiserer forfatteren karikatur ikke bare på tekstens overflade, men hun benytter sig også af den karikerende teknik til at opbygge figurens beskrivelse. Det gælder dog ikke en typisk litterær karikatur, fordi der ikke henvises til nogen kendte mennesker eller samfundsgrupper eller samfundslag, som læseren nemt kunne genkende, og de bliver heller ikke satirisk fremstillet. Den karikerende skrivestil bliver anvendt til forskellige formål, den mest markante brug fremgår af sammenligning af figurer, som bliver beskrevet på den samme karikerende måde. Ved at fremhæve ét og det samme karakteristiske træk lykkes det Blixen at skabe nogle depersonaliserede arketyper, som dukker op i flere af hendes fortællinger og er kendetegnede ikke bare ved det samme udseende, men også ved de samme egenskaber eller den samme samfundsstilling. Når der forekommer høje kvinder hos Blixen, kan man næsten sikkert regne med, at de har en stærk karakter med tendens til emantipation, når der forekommer tykke mænd, er de rige og mægtige. Blixens arketyper vidner om lighed mellem en række figurer i hendes persongalleri samt om variation af nogle lignende temaer og motiver i flere fortællinger, som fx kvindernes stilling i ægteskabet og i det daværende samfund generelt. Endvidere kan en karikerende fremhævelse af en kropsdel få en symbolsk betydning i forhold til figurens karakter og antyde dennes rolle i handlingen.

I fortællingen „Vejene omkring Pisa“ forekommer den tanke, at vores væsen genspejles i andre menneskers bevidsthed som en karikatur, fordi den aldrig helt kan ligne vores virkelige jeg. Karen Blixens fortællinger synes at virke på samme måde: de tilbyder mangfoldige fortolkninger og bliver forskelligt forstået af folk uden at man entydeligt kan bestemme deres væsen. Ved at påpege Blixens brug af den karikerende skrivestil ved figurernes beskrivelse kan man ikke komme til fortællingens kerne, men man kan gøre vejen til den lettere. ${ }^{6}$

\section{LITTERATUR}

Asmussen, Marianne Wirenfeldt og Stenkjær, Sofie, ed. Karen Blixens kunst = The Art of Karen Blixen: tegninger og malerier. Rungstedlund: Karen Blixen Museet, 2002.

Blixen, Karen. „Til fire kultegninger.“ Karen Blixens Tegninger. Ed. Frans Lasson. København: Forening for Boghaandværk, 1969. 19-29.

Blixen, Karen. Sidste fortcellinger. København: Gyldendal, 1957.

Blixen, Karen. Syv fantastiske fortcellinger. København: Gyldendal, 1988.

Blixen, Karen. Vintereventyr. København: Gyldendal, 1978.

Butzer, Günter, ed. Metzler Lexikon literarischer Symbole. Stuttgart: Metzler, 2012.

Engberg, Charlotte. Billedets ekko: om Karen Blixens fortoellinger. København: Gyldendal, 2000.

Gernhard, Robert. Theorie und Lyrik. Erfolgreiche komische Literatur in ihrem gesellschaftlichen und medialen Kontext. Münster: Waxmann, 2011.

6 The work was supported by the European Regional Development Fund-Project "Creativity and Adaptability as Conditions of the Success of Europe in an Interrelated World" (No. CZ.02.1.01/0.0/0.0/16 _019/0000734). 
Henriksen, Liselotte. Blixikon: Karen Blixen fra A til Å. København: Gyldendal, 1999.

Lasson, Frans, ed. Karen Blixens Tegninger. København: Forening for Boghaandværk, 1969.

Schnurbein, Stefanie von. „Genuss und Gefahr. Essen und Körper in ,Babettes Gæstebud'“ Karen Blixen / Isak Dinesen / Tania Blixen: Eine internationale Erzählerin der Moderne. Ed. Heike Peetz. Berlin: Nordeuropa-Inst. der Humboldt-Univ., 2008. 135-150.

Sturgis, Alexander og Clayson, Hollis. Faszination Malerei. Stuttgart: Belser, 2006.

\author{
Radka Stahr \\ Charles University \\ E-mail: radka.stahr@ff.cuni.cz
}

